\title{
Pelatihan Komputer Program Microsoft Excel Kepada Pengurus JPZISNU Ranting Sedayu - Turen
}

\author{
Kristina W. ${ }^{* 1}$, Aad H. ${ }^{2}$, Ahmad W. Purwandi ${ }^{3}$, Hudiono ${ }^{4}$, Ridho H.Y.P. ${ }^{5}$, Divac N.A. ${ }^{6}$ \\ 1,2,3,4,5,6 Jurusan Teknik Elektro, Politeknik Negeri Malang \\ e-mail: *,1 kristina@polinema.ac.id, ${ }^{2}$ aad.hariadi@polinema.ac.id
}

\begin{abstract}
Abstrak
JPZISNU (Jaringan Pengumpul Zakat, Infaq dan Shadaqah Nahdlatul Ulama) di ranting Sedayu, Kecamatan Turen Kabupaten Malang, merupakan suatu organisasi di bawah pengawasan BAZNAS (Badan Amil Zakat Nasional) berperan sebagai pengumpul zakat masyarakat di tingkat ranting (desa/kelurahan). Sifat keanggotaan JPZISNU adalah secara sukarela. JPZISNU memiliki kewajiban utama melaporkan data keuangan yang dikelola, kegiatan yang dilakukan, serta ianah syariah lainnya. Dengan demikian, penggunaan program berbasis komputer, khususnya Microsoft Excel, akan sangat membantu dalam penyusunan laporan ke badan pusat. Pada kenyataannya, pengurus JPZISNU Ranting Sedayu saat ini hanya terbatas dua orang yang mampu mengoperasikan Microsoft Excel untuk menyusun laporan keuangan. Didasari kenyataan itulah maka gagasan untuk melaksanakan kegiatan PPM (Pengabdian Pada Masyarakat) berupa Pelatihan Program Komputer Microsoft Excel diberikan kepada pengurus JPZISNU. Tujuan PPM ini adalah memperkenalkan dan memberikan pelatihan komputer program Microsoft Excel kepada pengurus JPZISNU ranting Sedayu. Dengan dilakukannya pelatihan Microsoft Excel, sangat membantu Pengurus JPZISNU dalam mengelola pencatatan keluar masuknya uang zakat, infaq, dan shadaqah dalam organisasi serta dapat membantu memudahkan penyusunan laporan pertanggungjawaban organisasi ke BAZNAS pusat.
\end{abstract}

Kata kunci-laporan keuangan, Microsoft Excel, pelatihan komputer

\section{PENDAHULUAN}

Pada era digitalisasi saat ini, baik di instansi pemerintah, organisasi, instansi swasta, perbankan, maupun pendidikan dituntut untuk dapat menggunakan teknologi dalam menyampaikan informasi serta bertukar data dengan akurat dan cepat. JPZISNU (Jaringan Pengumpul Zakat, Infaq dan Shadaqah Nahdlatul Ulama) merupakan suatu organisasi dibawah pengawasan BAZNAS (Badan Amil Zakat Nasional) yang berperan sebagai pengumpul zakat masyarakat di tingkat ranting (desa/kelurahan). Sifat keanggotaan JPZISNU adalah volunteer atau secara sukarela. JPZISNU memiliki kewajiban utama melaporkan data keuangan yang dikelola, sejumlah kegiatan yang dilakukan, serta ianah syariah lainnya. Dalam hal ini JPZISNU dituntut untuk selalu tepat waktu dan akurat dalam membuat laporan penanggungjawaban keuangan yang dikelolanya. Laporan dari tingkat ranting akan diteruskan ke tingkat regional yaitu MWCNU (Majelis Wakil Cabang Nahdlatul Ulama) dan LAZISNU (Lembaga Amil Zakat, Infaq, dan Shadaqah Nahdlatul Ulama) yang kemudian dilaporkan kepada BAZNAS pusat [1].

Kegiatan yang dilakukan LAZISNU meliputi pengumpulan dana untuk zakat dan distribusinya. Pelaksanaan pengumpulan dana zakat yang dilakukan oleh LAZISNU dalam bentuk fundraising, meliputi pengumpulan koin NU, menemui secara langsung para muzakki, melalui kotak, media sosial, mediasi para tokoh, dan lain sebagainya. Sedangkan dalam pendistribusiannya terbagi dalam dua hal yaitu secara komsumtif (bantuan langsung), maupun bantuan produktif (pemberdayaan ekonomi masyarakat). Semua kegiatan tersebut akan dilakukan pelaporan data keuangan dari tingkat ranting yaitu JPZISNU (desa/kelurahan) hingga BAZNAS pusat [2].

Kelurahan Sedayu adalah suatu kelurahan/desa dimana terletak pada wilayah Kecamatan Turen, Kabupaten Malang. Kelurahan Sedayu memiliki organisasi JPZISNU di tingkat ranting yang terdaftar pada badan LAZISNU. Dalam mengelola data keuangan, kendala pengurus JPZISNU di ranting Kelurahan Sedayu adalah sistem administrasi yang sebagian besar masih bersifat konvensional. Hal tersebut dikarenakan sumber daya manusia yang memiliki keterampilan administrasi berbasis komputer masih sangatlah minim. Dengan 
demikian sering terjadi keterlambatan pembuatan laporan pertanggungjawaban karena pengelolaan data hanya dikerjakan oleh beberapa anggota yang mumpuni saja.

Dalam pengelolaan data keuangan, JPZISNU ranting Sedayu masih bersifat konvensional, kemudian pengelolaan data untuk pembuatan laporan terpusat pada satu penanggungjawab saja. JPZISNU di ranting Kelurahan Sedayu terdiri dari 25 anggota pengurus, namun dari seluruh anggota hanya dua diantaranya yang mampu mengelola data keuangan dengan komputer program Microsoft Excel. Dengan demikian pembuatan laporan pertanggungjawaban hanya terbatas dapat dikerjakan oleh dua pengurus tersebut. Laporan pertanggungjawaban keuangan JPZISNU terdiri atas laporan keuangan bulanan dan akhir tahun.

Bedasarkan gagasan tersebut, maka para civitas akademika Politeknik Negeri Malang, khususnya Jurusan Teknik Elektro melakukan kegiatan PPM (Pengabdian Pada Masyarakat) berupa pelatihan program komputer Microsoft Excel diberikan kepada seluruh pengurus JPZISNU ranting Sedayu Kecamatan Turen untuk membantu dalam mengelola data keuangan dan menyelesaikan permasalahan pengerjaan laporan pertanggungjawaban JPZISNU ke BAZNAS pusat.

Tujuan kegiatan pengabdian kepada masyarakat ini adalah memperkenalkan dan memberikan pelatihan komputer program Microsoft Excel kepada pengurus JPZISNU ranting Sedayu, Kecamatan Turen, Kabupaten Malang dan untuk memudahkan anggota pengurus dalam mengelola data keuangan dan membuat laporan pertanggungjawaban JPZISNU. Sasaran target adalah seluruh pengurus JPZISNU ranting Sedayu, Kecamatan Turen, Kabupaten Malang. Target dari pelaksanaan PPM ini adalah seluruh anggota pengurus JPZISNU ranting Sedayu mampu mengoperasikan program Microsoft Excel, seluruh anggota pengurus mampu mengakses dan mengisi lembar spreadsheet sebagai media pertukaran data pengelolaan keuangan organisasi dan diharapkan kedepannya seluruh anggota mampu menyusun laporan pertanggungjawaban JPZISNU dengan alat bantu program Microsoft Excel.

Microsoft Office Excel merupakan sebuah program aplikasi pengolah angka buatan Microsoft Corporation. Excel adalah program spreadsheet dalam sistem Microsoft Office, dimana dalam penggunaannya Excel mampu menampilkan data, mengolah data, menghitung, membuat gambar diagram, pelaporan, dan semua hal yang berkaitan dengan data yang berupa angka [3]. Microsoft Excel adalah program spreadsheet yang digunakan untuk merekam dan menganalisis data numerik dan statistik. Microsoft Excel menyediakan banyak fitur untuk melakukan berbagai operasi seperti perhitungan, tabel pivot, alat grafik, pemrograman makro. Secara khusus, Excel dapat digunakan dalam pelacakan data, menganalisis data, menggunakan rumus matematika, serta untuk tampilan penyajian data dalam berbagai tampilan grafik [4].

Worksheet merupakan kumpulan baris dan kolom. Ketika baris dan kolom bertemu, keduanya membentuk sel. Sel digunakan untuk merekam data. Setiap sel diidentifikasi secara unik menggunakan alamat sel. Kolom biasanya diberi label dengan huruf sedangkan baris biasanya berupa angka. Lembar keja dalam Microsoft Excel dalam satu sheet terdiri dari 65536 baris dan 256 kolom. Misalkan perpotongan baris ke-5 dengan kolom B disebut sel B5. Sel dikatakan dalam keadaan aktif jika bergaris tebal [5].

Pelaporan keuangan sangat membutuhkan ketelitian tinggi dalam pencatatannya. Dengan mempelajari Microsoft Office Excel, pelaporan keuangan menjadi mudah untuk dilakukan. Manfaat lainnya adalah kemudahan dalam pengurutan angka, mengatur tata letak data, dan juga pengolahan data.

Microsoft Office Excel memungkinkan pengguna untuk mengatur tata letak data teks dalam format spreadsheet atau buku kerja. Lembar kerja dan buku kerja Excel dapat digunakan untuk membawa data dari berbagai file dan untuk diolah dan dianalisis. Kelebihan lain adalah pengguna mudah untuk memformat dan mengatur ulang data yang berguna ketika menyajikan serangkaian data yang relevan dengan topik yang sama. Penggunaan Microsoft Office Excel digunakan juga untuk memproses data dan menganalisis dengan grafik dan bagan. Dengan demikian, pengguna dapat dengan mudah menganalisis data.

\section{METODE}

Untuk menunjang keahlian pengurus JPZISNU ranting Sedayu pada bidang teknologi informasi dilakukan dengan pendekatan memberikan pelatihan menggunakan modul. Sebelum dilakukan pelatihan, seluruh pengurus diberikan soal yang berupa kuesioner (pre-test) untuk mengetahui pengetahuan dasar mengenai program Microsoft Excel. Setelah itu pelaksanaan pelatihan program Microsoft Excel kepada pengurus JPZISNU ranting Sedayu dilakukan oleh tim PPM dibantu narasumber dengan keahlian tersebut, dimana materi pelatihan terdiri dari: 
1. Pengantar Microsoft Excel

2. Tutorial

3. Pendalaman materi Microsoft Excel

4. Praktik Mandiri

5. Tanya Jawab

Pada kegiatan tatap muka, akan dilakukan pembekalan mengenai pengenalan program kepada pengurus JPZISNU yang berjumlah 25 anggota pengurus, namun karena pelaksanaan pengabdian di era pandemi maka hanya 12 perwakilan pengurus JPZISNU yang hadir. Pada tatap muka tersebut, kelompok dibagi menjadi 6 kelompok (satu kelompok 2 orang). Satu kelompok akan menggunakan satu laptop untuk praktik secara bergantian menggunakan laptop inventaris kantor JPZISNU ranting Sedayu sejumlah 6 buah. Setiap anggota juga diberikan modul tutorial penggunaan program Microsoft Excel.

Narasumber pada pelatihan ini menjelaskan materi Microsoft Excel menggunakan media LCD, dengan tujuan agar peserta lebih memahami dengan lebih jelas sesuai dengan panduan modul yang telah diberikan. Setiap peserta melakukan praktik berupa proses menjalankan komputer, membuka lembar kerja Microsoft Excel, pengenalan menu dari Microsoft Excel, menggunakan formulasi, dan pengisian data secara bersama melalui lembar spreadsheet yang telah diberikan oleh narasumber. Dengan demikian narasumber dapat langsung mengevaluasi pemahaman pengelolaan data terhadap anggota pengurus karena dapat dipantau dari lembar kerja spreadsheet. Selama pelatihan, semua anggota dapat mengajukan pertanyaan secara langsung kepada narasumber maupun Tim Pengabdian Pada Masyarakat yang mendampingi selama pelatihan dilaksanakan. Pada pertemuan terakhir pelatihan, akan dilakukan post-test dan angket berupa kuesioner.

\subsection{Metode Kegiatan}

Metode kegiatan pelaksanaan pengabdian pada masyarakat ini disajikan pada Tabel 1 berikut ini.

Tabel 1 metode pelaksanaan kegiatan

\begin{tabular}{|c|l|}
\hline No. & \multicolumn{1}{|c|}{ Kegiatan } \\
\hline 1. & $\begin{array}{l}\text { Survei dan analisis data primer ke Pengurus } \\
\text { JPZISNU Ranting Sedayu Kecamatan Turen }\end{array}$ \\
\hline 2. & $\begin{array}{l}\text { Penjelasan kegiatan dan penandatanganan } \\
\text { kontrak dengan Pengurus JPZISNU Ranting } \\
\text { Sedayu Kecamatan Turen }\end{array}$ \\
\hline
\end{tabular}

\begin{tabular}{|c|l|}
\hline No. & \multicolumn{1}{|c|}{ Kegiatan } \\
\hline 3. & $\begin{array}{l}\text { Pre test untuk seluruh Pengurus JPZISNU } \\
\text { Ranting Sedayu Kecamatan Turen }\end{array}$ \\
\hline 4. & $\begin{array}{l}\text { Pelaksanaan kegiatan dan pelatihan program } \\
\text { computer Microsoft Excel 2013 kepada } \\
\text { Pengurus JPZISNU Ranting Sedayu } \\
\text { Kecamatan Turen }\end{array}$ \\
\hline 5. & $\begin{array}{l}\text { Post test untuk semua Pengurus JPZISNU } \\
\text { Ranting Sedayu Kecamatan Turen }\end{array}$ \\
\hline 6. & Monitoring dan evaluasi \\
\hline
\end{tabular}

\subsection{Pelaksanaan}

Pelaksanaan program Pengabdian pada Masyarakat (PPM) dilaksanakan di TPQ Masjid Riyadlun Nahdliyyin Kelurahan Sedayu karena kantor JPZISNU masih dalam proses perbaikan.

Sebelum pelaksanaannya, seluruh anggota diminta mencuci tangan terlebih dahulu dan memakai masker serta menjaga jarak sesuai dengan protokol kesehatan di era pandemi (Gambar 1). Peserta kemudian diberikan seminar kit berupa map, alat tulis, buku tulis, serta buku panduan (Gambar 2) dan lembar pre-test. Setelah kegiatan berlangsung, dibagikan lembar post-test serta angket kebermanfaatan pelatihan sebagai alat evaluasi.

\section{/}

Gambar 1 Kegiatan mencuci tangan sebelum memulai pelatihan

Sebelum memulai pemaparan materi, peserta terlebih dahulu mengisi soal pre-test untuk mengetahui pengetahuan umum peserta sebelum dilakukan pemaparan materi dan pelatihan. Kemudian peserta diberi penjelasan mengenai materi Microsoft Excel terlebih dahulu. Materi diawali dengan penjelasan mulai awal, yaitu menginstall aplikasi, kemudian bagaimana membuka aplikasi dan mengenalkan elemen dan menu-menu yang tersedia.

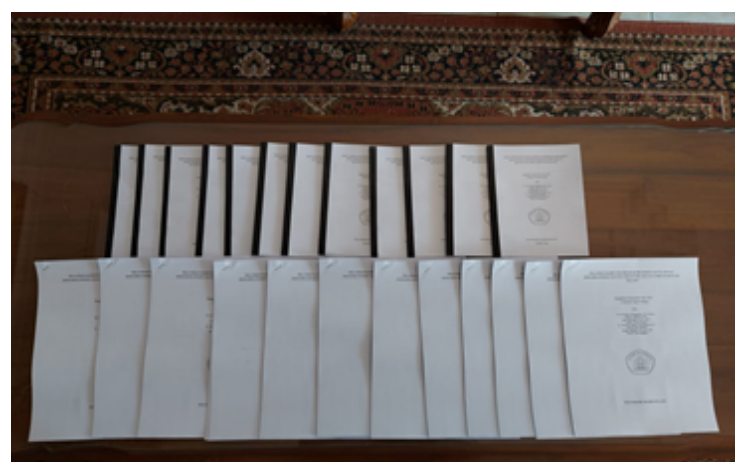

Gambar 2 Panduan pelatihan Microsoft Excel 
Misalnya Ribbon, dirancang untuk membantu menemukan perintah dengan cepat. Perintah dikumpulkan di bawah $T a b$. Setiap $T a b$ berkaitan dengan jenis aktivitas, seperti memformat atau meletakkan halaman. Menu File membantu menemukan perintah dasar seperti buka, simpan, cetak, dan lainnya. Formula Bar adalah tempat yang digunakan untuk memasukkan atau melihat rumus atau teks.

Untuk memulai program Microsoft Excel, dapat dilakukan search pada kolom windows dan mengetik "Excel". Setelah itu klik dan buka workbook pada programnya. Setelah program terbuka, maka akan tampil berbagai menu pada lembar kerja Excel, diantaranya ditunjukkan pada Gambar 3.

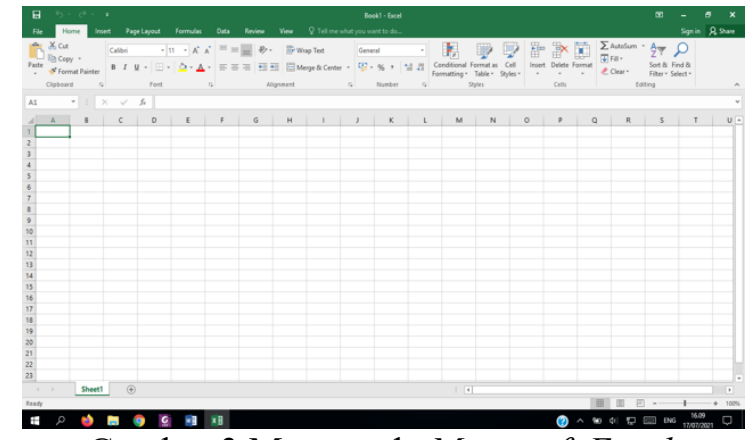

Gambar 3 Menu pada Microsoft Excel

Bagian-bagian pada Microsoft Excel di antaranya adalah sebagai berikut [6].

\section{a) Menu Bar}

Menu ini untuk melakukan suatu command, antara lain adalah File, Insert, Home, Formulas, Page Layout, Data, View, dan Review.

b) Title Bar

Title bar terdiri dari beberapa komponen, antara lain:

- Icon Control Menu

- Size, berhubungan dengan ukuran layar jendela

- Minimize, mengatur jendela ke ukuran terkecil

- Maximize, mengatur jendela ke ukuran terbesar

- Close, keluar dari aplikasi

\section{c) Formula bar}

Formula Bar adalah tempat data atau rumus yang dimasukkan ke dalam lembar kerja dimana muncul untuk sel yang aktif. Formula Bar juga dapat digunakan untuk mengedit data atau formula di sel yang aktif.

\section{d) Petunjuk Sel (Cell Pointer)}

Cell Pointer untuk memindahkan penunjuk sel ke tempat baru. Apabila menggunakan keyboard, maka langkah yang dilakukan disajikan pada Tabel 2.

Tabel 2 contoh petunjuk sel

\begin{tabular}{|c|l|}
\hline Tanda & \multicolumn{1}{|c|}{ Keterangan } \\
\hline$\longrightarrow$ & Memindai 1 sel ke sel sesuai arah panah \\
\hline Enter & Memindai ke bawah 1 sel \\
\hline Home & Memindai ke kolom A \\
\hline Ctrl+Home & Memindah ke awal worksheet \\
\hline Page Down & Memindai 1 layar ke bawah \\
\hline
\end{tabular}

Penggunaan rumus merupakan keunggulan utama dari aplikasi ini. Salah satu manfaat menggunakan program spreadsheet adalah kemampuan untuk membuat rumus dalam satu sel dan menyalinnya ke sel lain. Dalam menggunakan rumus matematika, dapat dilakukan penghitungan atau tindakan lain pada data di lembar kerja. Penggunaan rumus dimulai dengan tanda sama dengan $(=)$. Pengguna dapat membuat rumus menggunakan nilai aktual, misalnya $10000 * .5$, tetapi lebih bermanfaat jika merujuk ke alamat sel dalam rumus, misalnya $\mathrm{A} 1 * .5$ karena pengguna sudah tidak perlu lagi menuliskan bilangan yang akan dioperasikan dalam formula. Operator dasar yang sering digunakan disajikan pada Tabel 3.

Pada microsoft Excel, lembar kerja adalah lembar bentang tunggal yang biasanya berisi label deskriptif, nilai numerik, rumus, fungsi, dan representasi grafis dari data. Lembar kerja (worksheet) adalah kumpulan dari satu atau lebih lembar kerja terkait yang terdapat dalam satu file [7]. Secara default, buku kerja baru berisi satu lembar kerja. Menyimpan beberapa lembar kerja dalam satu buku kerja membantu mengatur data terkait bersamasama dalam satu file dan memungkinkan untuk melakukan perhitungan di antara lembar kerja dalam buku kerja. Fungsi formula dasar adalah untuk melakukan penghitungan terhadap data. Penulisan formula diawali dengan tanda sama dengan (=). Apabila input tidak memenuhi kriteria, maka hasil yang muncul akan bernilai salah (\#VALUE).

Tabel 3 operator dasar Excel

\begin{tabular}{ccl}
\hline No. & Operator & \multicolumn{1}{c}{ Fungsi } \\
\hline 1. & $=$ & Memulai formula \\
\hline 2. & + & Penambahan \\
\hline 3. & - & Pengurangan \\
\hline
\end{tabular}




\begin{tabular}{ccl}
\hline No. & Operator & \multicolumn{1}{c}{ Fungsi } \\
\hline 4. & $*$ & Perkalian \\
\hline 5. & $/$ & Pembagian \\
\hline 6. & $\%$ & Persen \\
\hline 7. & $\wedge$ & Pangkat \\
\hline
\end{tabular}

a) Aritmatika Dasar

Fungsi penambahan (+), pengurangan (-), perkalian $(*)$, dan pembagian $(/)$.

b) SUM

Berfungsi untuk menjumlahkan bilangan pada suatu rentang. Sintaknya adalah $=\operatorname{SUM}($ bil1, bil2, .....) kemudian tekan Enter.

c) MIN

Digunakan untuk mencari nilai terendah dari sekumpulan bilangan pada rentang Sintaknya adalah $=$ MIN (bill, bil2,.....) kemudian tekan Enter.

d) MAX

Digunakan untuk mencari nilai tertinggi dari sekumpulan bilangan pada rentang. Sintaknya adalah $=$ MAX $($ bil1, bil2,.....) kemudian tekan Enter.

e) COUNT

Berfungsi menghitung jumlah bilangan pada suatu rentang. Sintaknya adalah =COUNT(nill, nil2,.....) kemudian tekan Enter.

f) PRODUCT

Digunakan untuk proses perkalian bilangan pada rentang. Sintaknya adalah $=$ PRODUCT(bill, bil $2, . . .$.$) kemudian tekan Enter.$

g) ROUND

Digunakan untuk pembulatan bilangan ke suatu digit tertentu. Sintaknya adalah $=$ ROUND(bil,digitbil) kemudian tekan Enter.

\section{h) AVERAGE}

Berfungsi untuk mencari rerata bilangan dalam rentang. Sintaknya adalah =AVERAGE (bil1,bil2,...) kemudian tekan Enter.

Rumus lain yang umum digunakan pada Excel adalah SUM, atau penambahan beberapa nilai. Misalnya pengguna akan menambahkan bilangan yang ada pada cell dengan alamat kolom A baris 1 ditambah bilangan pada cell kolom B baris 5, kemudian dikurangi bilangan pada cell kolom $\mathrm{E}$ baris 2 adalah dengan mengetikkan $=\mathrm{A} 1+\mathrm{B} 5-\mathrm{E} 2$. Dengan menekan ENTER, pengguna dapat memperoleh hasil operasi tersebut.

Kekuatan Excel terletak pada kemampuannya untuk melakukan perhitungan. Salah satu fasilitas yang dimiliki adalah fungsi Function. Function adalah rumus yang lebih kompleks yang dieksekusi menggunakan nama fungsi. Beberapa fungsi pada Excel yang sering digunakan disajikan pada Tabel 4.

Tabel 4 operator function

\begin{tabular}{|c|l|l|}
\hline No. & \multicolumn{1}{|c|}{ Operator } & \multicolumn{1}{c|}{ Fungsi } \\
\hline 1. & $=$ SUM(rentang sel) & $\begin{array}{l}\text { Menjumlah bilangan yang } \\
\text { ada pada rentang sel }\end{array}$ \\
\hline 2. & $\begin{array}{l}\text { =AVERAGE(rentang } \\
\text { sel) }\end{array}$ & $\begin{array}{l}\text { Menghasilkan rata-rata } \\
\text { bilangan yang ada pada } \\
\text { rentang sel }\end{array}$ \\
\hline 3. & $=$ MAX(rentang sel) & $\begin{array}{l}\text { Menghasilkan numerik } \\
\text { tertinggi yang ada pada } \\
\text { rentang sel }\end{array}$ \\
\hline 4. & $=$ MIN(rentang sel) & $\begin{array}{l}\text { Menghasilkan numerik } \\
\text { terendah yang ada pada } \\
\text { rentang sel }\end{array}$ \\
\hline 5. & $=$ COUNT(rentang sel) & $\begin{array}{l}\text { Menghitung banyak sel } \\
\text { yang berisi bilangan yang } \\
\text { ada pada rentang sel }\end{array}$ \\
\hline
\end{tabular}

\section{HASIL DAN PEMBAHASAN}

Dalam memberikan pelatihan, peserta diberikan latihan dari dasar terlebih dahulu. Misalkan diberikan data seperti yang disajikan pada Gambar 4 . Peserta dikenalkan istilah yang paling dasar, yaitu alamat dari suatu sel. Ditunjukkan bahwa setiap sel memiliki alamat yang unik. Bilangan 5 terletak pada kolom A baris 1, bilangan 2 terletak pada kolom A baris 2, dan bilangan 4 terletak pada kolom A baris 5 .

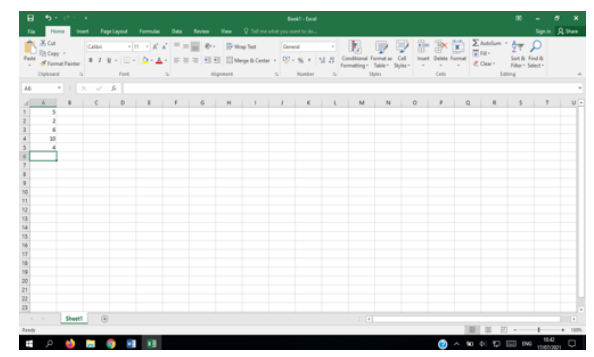

Gambar 4 Contoh pengenalan alamat sel

Untuk mengenalkan bagaimana mengoperasikan penjumlahan, diberikan contoh sederhana, yaitu menjumlah bilangan 5 dan 2 . Peserta dapat menggunakan operator $=\mathrm{A} 1+\mathrm{A} 2$, baik dengan cara menuliskan alamat sel atau dengan klik sel A1 dan A2 (Gambar 5a). Demikian juga apabila ingin menjumlah bilangan pada rentang sel A1 sampai 
dengan A5, dapat menggunakan fasilitas fungsi SUM(A1:A5) seperti disajikan pada Gambar 5b.

\begin{tabular}{|c|c|c|c|c|c|}
\hline \multicolumn{2}{|c|}{ A2 } & $\vdots$ & $\times \checkmark$ & $f_{x}$ & $=A 1+A 2$ \\
\hline$\Delta$ & A & B & $C$ & [ & $E$ \\
\hline 1 & $5 \mid$ & & $=A 1+A 2$ & & \\
\hline 2 & 2 & & & & \\
\hline 3 & 6 & & & & \\
\hline 4 & 10 & & & & \\
\hline 5 & 4 & & & & \\
\hline 6 & & & & & \\
\hline
\end{tabular}

(a)

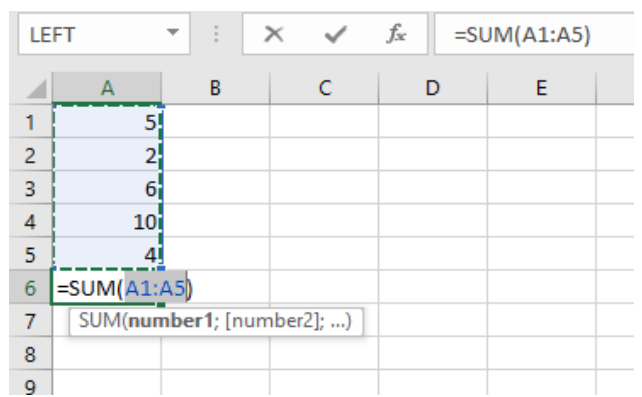

(b)

Gambar 5 Contoh operator penjumlahan

Setelah penjelasan materi, anggota pengurus JPZISNU melakukan praktik bersama pada lembar spreadsheet yang telah disediakan oleh tim pengabdian dan narasumber secara online (Gambar 6), sehingga narasumber bisa secara langsung mengevaluasi apakah peserta telah paham terhadap materi yang diberikan dalam praktiknya sesuai dengan lembar kerja masing-masing anggotanya.

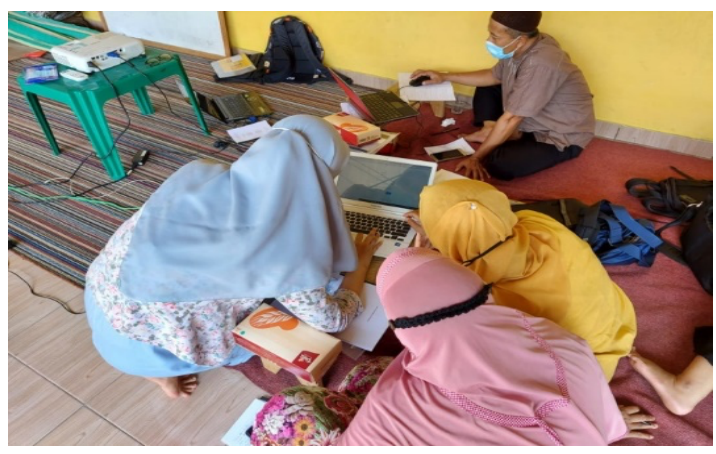

Gambar 6 Tim Pengabdian Melakukan Pendampingan kepada Peserta Pelatihan

Pendampingan pada saat pelatihan berlangsung sangat penting dilakukan karena peserta pelatihan dapat secara langsung mengajukan pertanyaan atau mengklarifikasi. Tim pengabdian memberikan latihan, seperti yang disajikan pada Gambar 7, yaitu spreadsheet online setiap kali selesai memberikan materi baru agar peserta dapat segera memahami materi yang disampaikan.

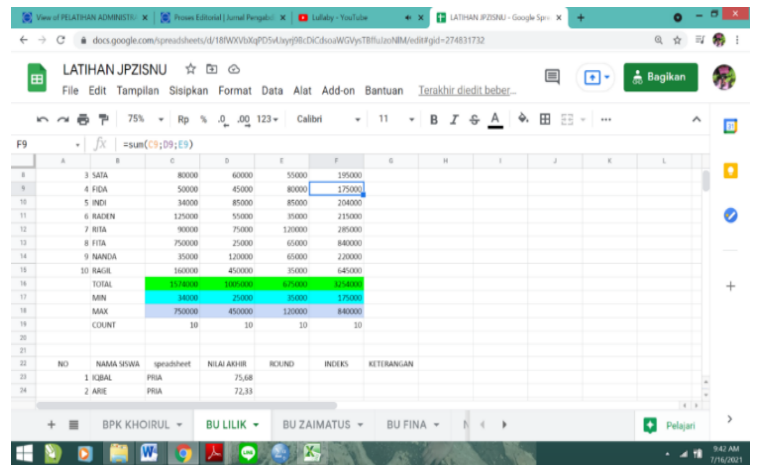

Gambar 7 Spreadsheet online untuk latihan anggota pengurus JPZISNU

Selama pelatihan berlangsung, peserta sangat antusias dalam berlatih. Hal ini ditunjukkan oleh sikap peserta yang tertib dalam mengikuti kegiatan, dan aktif bertanya kepada tim pengabdian. Situasi selama kegiatan pelatihan berlangsung disajikan dalam Gambar 8.

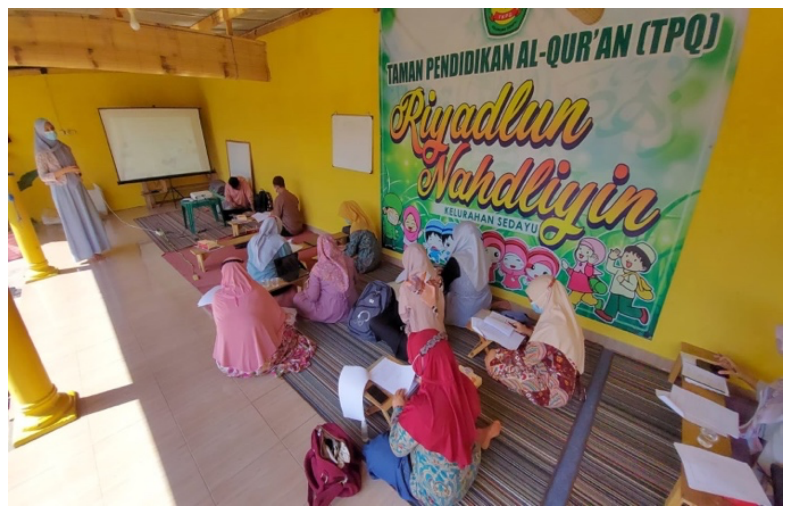

Gambar 8 Pelaksanaan kegiatan pelatihan

\subsection{Evaluasi}

Evaluasi pelaksanaan program Pengabdian Pada Masyarakat dilakukan dengan dua cara yaitu:

a) Evaluasi terhadap penyerapan materi Microsoft Excel yang telah diberikan melalui pemberian soal pre-test dan post-test yang sesuai dengan materi. Dengan demikian dapat dilihat peningkatan pemahaman peserta sebelum dan setelah pemaparan maupun praktik materi.

b) Evaluasi terhadap kebermanfaatan kegiatan dilakukan dengan pemberian angket kepada peserta untuk mengetahui kebermanfaatan serta kritik dan saran selama pelaksanaan kegiatan.

Hasil evaluasi disajikan pada Tabel 5. 
Tabel 5 Hasil evaluasi pre-test dan post-test

\begin{tabular}{|l|l|c|c|c|c|c|}
\hline No. & Nama & Skor & $\begin{array}{c}\text { Pre } \\
\text { Test }\end{array}$ & Skor & $\begin{array}{c}\text { Post } \\
\text { Test }\end{array}$ & $\begin{array}{c}\text { Skor } \\
\text { Manfaat }\end{array}$ \\
\hline 1. & Choirul & 10 & 50 & 20 & 100 & 34 \\
\hline 2. & Lilik & 12 & 60 & 18 & 90 & 40 \\
\hline 3. & Nur Azizah & 14 & 70 & 18 & 90 & 37 \\
\hline 4. & Deasy & 5 & 25 & 19 & 95 & 39 \\
\hline 5. & Badriyah & 5 & 25 & 19 & 95 & 33 \\
\hline 6. & Khamidah & 11 & 55 & 20 & 100 & 34 \\
\hline 7. & Nafiatun & 7 & 35 & 12 & 60 & 27 \\
\hline 8. & Zaimatus & 10 & 50 & 18 & 90 & 33 \\
\hline 9. & Wartini Sri & 13 & 65 & 15 & 75 & 40 \\
\hline 10. & Fina & 10 & 50 & 18 & 90 & 40 \\
\hline 11. & Rohmawati & 9 & 45 & 20 & 100 & 40 \\
\hline & Rata-rata & $\mathbf{9 . 6 4}$ & $\mathbf{4 8 . 1 8}$ & $\mathbf{1 7 . 9 1}$ & $\mathbf{8 9 . 5 5}$ & $\mathbf{3 6 . 0 9}$ \\
\hline
\end{tabular}

Pada Tabel 6 menunjukkan rata-rata pemahaman umum peserta terhadap Microsoft Excel sebelum pemaparan materi dan praktik adalah sebesar $48.18 \%$, sedangkan setelah pemaparan materi dan praktik meningkat menjadi $89.55 \%$. Hal tersebut menunjukkan adanya peningkatan pemahaman sebesar $41.37 \%$. Sedangkan pada skor kebermanfaatan pelaksanaan kegiatan didapatkan total rata-rata jawaban peserta sebesar $36.09 / 40$ pada kegiatan ini bermanfaat.

Tabel 6 Rata-rata Pemahaman Umum Peserta

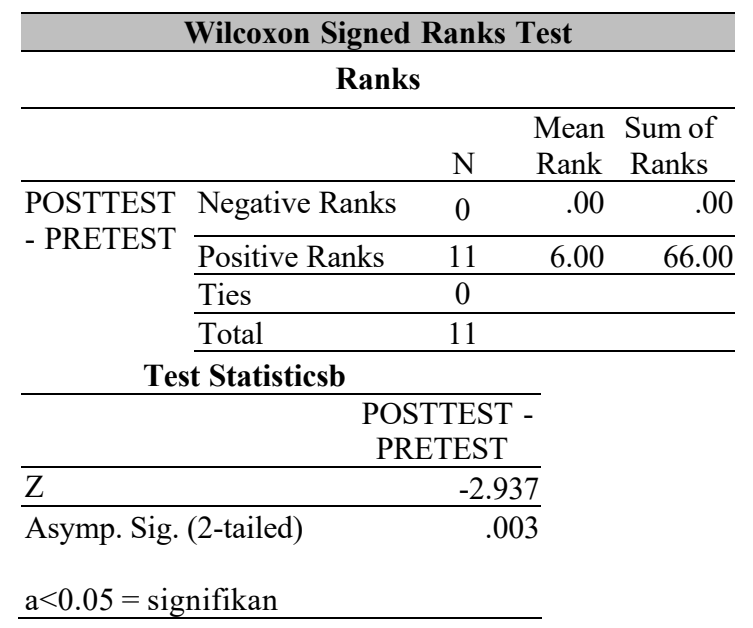

Analisa data menggunakan Uji Wilcoxon disajikan pada Tabel 6. Hasil uji statistik terhadap peningkatan pemahaman peserta pelatihan menunujukkan hasil yang signifikan $(\mathrm{a}<0.05)$. Dengan demikian pada pelaksanaan kegiatan ini materi dapat diterima dan dipraktikkan oleh peserta dengan baik. Pemahaman yang baik dari peserta pelatihan sangat bermanfaat bagi penyusunan laporan pertanggungjawaban organisasi ke BAZNAS pusat.

\section{KESIMPULAN}

Kegiatan Pengabdian Pada Masyarakat (PPM) yang dilaksanakan melalui pelatihan program komputer Microsoft Excel pada pengurus JPZISNU Ranting Sedayu Kecamatan Turen Kabupaten Malang telah dapat dilaksanakan dengan lancar di TPQ Riyadlun Nahdliyyin Kelurahan Sedayu. Kegiatan ini melibatkan tim pengabdian kepada masyarakat yaitu dosen serta mahasiswa Jurusan Teknik Elektro. Pelatihan dilakukan dalam dalam bentuk presentasi materi, praktik secara langsung, serta tanya jawab.

Peserta pengabdian yaitu anggota pengurus JPZISNU Ranting Sedayu Kecamatan Turen memiliki antusiasme yang sangat baik. Peserta mempunyai semangat yang tinggi setelah mengetahui manfaat program Microsoft Excel dalam mengelola berbagai data keuangan. Dalam angket yang diisi oleh peserta, para anggota pengurus JPZISNU berharap adanya pelatihan lanjutan untuk meningkatkan pengetahuan dan keterampilan pengurus. Peserta juga menyatakan pelatihan ini sangat bermanfaat bagi lembaga mereka dan penggunaan program Microsoft Excel sangat membantu dalam menyelesaikan data laporan pertanggungjawaban lembaga JPZISNU.

\section{SARAN}

a) Saran dari peserta dalam pelaksanaannya, kegiatan ini dapat berlanjut menjadi kerjasama dengan lembaga JPZISNU dan jejaringnya. Tidak hanya program Microsoft Excel, namun program yang lain seperti Microsoft Word dan Microsoft Presentation Power Point.

b) Para peserta menyarankan agar kegiatan dilajutkan kepada anggota pengurus lain yang tidak dapat hadir dikarenakan keterbatasan kuota peserta (karena menyesuaikan ketentuan PPKM), sehingga seluruh anggota pengurus dapat secara merata mendapatkan materi dan pelatihan dari kegiatan ini.

c) Dalam pelaksanaannya di era pandemi ini, perlu ditinjau ulang untuk pelaksanannya agar sesuai dengan prosedur protokol kesehatan yang ada. Lebih waspada dan lebih menekankan kepada peserta agar selalu menjaga jarak.

\section{UCAPAN TERIMA KASIH}

Penulis menyampaikan terima kasih kepada Politeknik Negeri Malang atas dukungan moral dan 
pendanaan terhadap program pengabdian masyarakat ini ini. Terima kasih juga penulis sampaikan kepada Pengurus JPZISNU Ranting Sedayu - Turen atas partisipasinya dalam mendukung pengenalan teknologi pada masyarakat.

\section{DAFTAR PUSTAKA}

[1] Anwar, A. T., 2018, Zakat Produktif untuk Pemberdayaan Ekonomi Umat, ZISWAF, No. 1, Vol. 5.

[2] Toriquddin, M., 2015, Pengelolaan Zakat Produktif di Rumah Zakat Kota Malang Perspektif Maqashid Al Syariah Ibnu 'Asyur di Kabupaten Malang, Jurnal Studi Islam, No. 1, Vol. 16.

[3] Yusri, R., Edriati, S., dan Yuhendri, R., 2020, Pelatihan Microsoft Office Excel sebagai Upaya Peningkatan Kemampuan Mahasiswa dalam Mengolah Data, Jurnal Pengabdian pada Masyarakat UP3M STKIP PGRI Sumatera Barat, No. 1, Vol. 2.

[4] Rahman, A., Yuridka, F., dan Sari, M., 2015, Pelatihan Komputer Program Microsoft Excel 2013 pada SMAN 12 Banjarmasin, Jurnal Pengabdian Al-Ikhlas Universitas Islam Kalimantan Muhammad Arsyad Al Banjary, Vol. 1.

[5] Jarot, S., Shenia, A., dan Sudarma, S., 2012, Buku Pintar Microsoft Office 2007 \& 2010: Word-Excel-PowerPoint, MediaKita.

[6] Direktorat Integrasi Data dan Sistem Informasi Institut Pertanian Bogor. 2017, Modul Pelatihan Microsoft Excel 2013, http://dsitd.ipb.ac.id/wpcontent/uploads/2017/10/Modul-PelatihanMicrosoft-Excel-2013-1.pdf, diakses tanggal 10 Juli 2021.

[7] Poatsy, M. A., 2017, Microsoft Excel 2016 Comprehensive, Pearson Education, Inc., Boston. 